\title{
RESISTENSI PONDOK PESANTREN DALAM MENGELOLA SANTRI DI MASA PANDEMI COVID-19
}

\author{
Hilmi Qosim Mubah \\ Program Studi Manajemen Pendidikan Islam IAIN Madura \\ hilmiqosimmubah@iainmadura.ac.id
}

\begin{abstract}
ABSTRAK
Kajian ini bertujuan untuk menguraikan bagaiamana pondok pesantren dalam mempertahankan diri dari pandemi Covid-19 yang sedang melanda di nusantara dengan mengaitkan dengan kajian manajemen pendidikan agar dapat memberi kontribusi yang baik bagi pendidikan pesantren dan dapat menghindarkan santri dari munculnya klaster baru Covid-19. Metode pembahasan menggunakan studi literatur dengan penguraian, perangkuman, serta penarikan kesimpulan dan berusaha untuk memunculkan gagasan-gagasan baru yang relevan dan mutakhir untuk dilaksanakan di dalam sistem manajemen pondok pesantren. Dari studi literatur yang telah dilakukan dapat diketahui bahwa pengelolaan santri dalam pondok pesantren agar terhindar dari Covid-19 merupakan hal wajib yang harus dilaksanakan oleh pondok pesantren. Pengelolaan santri secara fisik dapat dilakukan dengan membentuk gugus Covid-19, menyediakan fasilitas protokol kesehatan, program kebersihan pondok, program olahraga rutin, penyediaan makanan santri yang higienis, pengurangan jumlah santri dalam satu kamar, santri diberi waktu istirahat yang cukup agar kekebalan tubuh tetap terjaga, bertindak cepat bila ada santri yang sakit, serta para pimpinan pesantren ikut serta dalam mengawasi para santri dalam kepatuhan terhadap protokol kesehatan. Selain itu di lingkup kurikulum pesantren, perlu adanya perubahan yang sesuai dengan karakteristik pembelajaran di masa pandemi dan tetap efektif dalam transfer ilmu pengetahuan dan agama kepada santri. Dalam pembelajaran pengelola pesantren hendaknya mengurangi jadwal kegiatan, menyediakan kelas daring dengan sistem blended learning membuka pesantren virtual dalam rangka mewadahi para santri dewasa yang masih ingin mengaji kepada para kiai.
\end{abstract}

Kata kunci: resistensi, manajemen santri, pandemi Covid-19

\section{ABSTRACT}

This study aims to describe how Islamic boarding schools defend themselves from the Covid-19 pandemic that is hitting the archipelago by linking it with education management studies so that they can make a good contribution to Islamic boarding school education and can prevent students from the emergence of new clusters of COVID-19. The method of the discussion uses literature studies with descriptions, summaries, concluding and seeks to bring up new ideas that are relevant and up-to-date to be implemented in the management 
system of Islamic boarding schools. From the literature study that has been carried out, it can be seen that the management of students in Islamic boarding schools to avoid Covid-19 is a mandatory thing that must be carried out by Islamic boarding schools. Physical management of students can be done by forming a covid-19 cluster, providing health protocol facilities, cottage hygiene programs, routine sports programs, providing hygienic food for students, reducing the number of students in one room, students being given sufficient rest time so that their immunity is maintained. act quickly if there are students who are sick, and the leaders of the pesantren participate in supervising the students in compliance with health protocols. In addition, within the scope of the Islamic boarding school curriculum, there needs to change that is by the characteristics of learning during the pandemic and remain effective in the transformation of science and religion to students. In learning, pesantren managers should reduce the schedule of activities, provide online classes with a blended learning system, open virtual pesantren to accommodate adult students.

Key words: resistance, student management, pandemic Covid-19

\section{PENDAHULUAN}

Lembaga pendidikan pesantren merupakan lembaga pendidikan Islam tertua di nusantara. Pondok pesantren dengan kapasitas sebagai tempat belajar sekaligus tempat tinggal para santri harus menjamin seluruh kebutuhan santri mulai dari kebersihan, kenyamanan, keamanan sampai kesehatan seluruh santri yang tinggal di pondok. Santri sebagai bagian yang utama dari pondok pesantren mempunyai peranan penting dalam keberlangsungan proses pendidikan di pesantren. Mereka datang dari berbagai daerah dengan latar belakang yang berbeda serta heterogenitas kultur, sosial-ekonomi dan latar pendidikan.

Pesantren sebagai sarana pendidikan Islam yang tidak sekedar mentransfer ilmu memiliki tantangan yang tidak mudah untuk menyambut new normal ditengah pandemi Covid-19. Berbagai prasyarat harus dipenuhi untuk bisa menghadirkan santri secara fisik di pesantren guna melakukan pembelajaran tatap muka. Alasan pembukaan pembelajaran tatap muka di pesantren karena pembelajaran sangat sulit dilakukan secara jarak jauh karena banyak kurikulum, metode, dan tradisi pendidikan pesantren yang memerlukan interaksi langsung selama 24 jam serta santri memerlukan bimbingan ibadah, keteladanan, dan uswah hasanah lainnya yang tidak mungkin bisa dijalankan dengan model pembelajaran jarak jauh (Haniek, 2020).

Santri membaur menjadi satu kesatuan yang tidak bisa terpisahkan dengan kiai, ustadz dan para pengurus lembaga pondok pesantren. Bahkan di pesantren terutama di dalam asrama, tidak ada pembedaan usia maupun daerah asal untuk bertempat tinggal dalam satu bilik kamar. Oleh karena itu dalam mengelola santri yang heterogen tersebut, pihak pengurus pondok pesantren harus memiliki manajemen dan sistem pengorganisasian yang baik agar semua santri mendapatkan hak-hak mereka dengan baik.

Prinsip kebersamaan dan persaudaraan selalu diterapkan dalam keseharian di lembaga pesantren. Sehingga di dalam lingkup pesantren, para santri makan, tidur, solat, serta memasak bersama dalam satu kesatuan komplek yang ada di dalam lingkungan pondok, sehingga dalam masa pandemi seperti 
sekarang protokol kesehatan wajib dilaksanakan demi menjaga imunitas serta resistensi santri dari berbagai macam penyakit terutama Covid-19.

Dalam penelitian terdahulu menyebutkan bahwa manajemen pondok pesantren di masa pandemi Covid-19 harus mengikuti himbauan dan juga kebijakan yang telah diputuskan oleh pemerintah dengan tetap berlandaskan kebijakan pembina dan pengasuh pesantren. Untuk itu diperlukan adanya training/pelatihan tanggap darurat bencana apapun (Kahfi \& Kasanova, 2020).

Pondok pesantren merupakan satu-satunya lembaga pendidikan yang telah menjalani proses tatap muka pada masa kenormalan baru (new normal). Ini berdasarkan keputusan Menteri Agama Fachrul Razi berdasarkan kesepakatan yang telah dibuatnya dengan Menteri Pendidikan dan Kebudayaan, Menteri Kesehatan, dan Menteri Dalam Negeri (Firmansyah, 2020).

Secara umum, semua lembaga pendidikan di Indonesia mulai dari tingkat usia dini sampai tinggi tidak ada yang berani melaksanakan kegiatan pembelajaran tatap muka. Kegiatan pembelajaran di masa Covid-19 ini dijalankan melalui mekanisme pembelajaran daring, meskipun ada beberapa sekolah yang melaksanakan pembelajaran tatap muka dengan memakai pakaian bebas agar tidak diketahui oleh gugus Covid setempat, namun pembelajaran tatap muka mereka pun tidak berlangsung lama karena pembagian kelas yang rumit dan ruang kelas yang kurang memadai. Berbeda dengan pondok pesantren, dalam serba keterbatasan baik bangunan asrama maupun kondisi kebersihan yang kurang, sejak masa new normal, pesantren sudah kembali normal dengan aktivitas mereka dengan pembelajaran tatap muka.

Pembelajaran daring bagi pesantren merupakan hal yang sulit dilakukan dengan berbagai alasan. Pondok pesantren yang merupakan lembaga pembentuk akhlak manusia paripurna tidak mungkin mentransfer moral dari omongan belaka. Di pondok pesantren, budaya menjadi suatu pembelajaran yang sangat baik dalam mendidik akhlak santri. Teladan para ustad, kiai dan para pengurus pondok menjadi patokan akhlak yang telah terverifikasi oleh Kiai bahwa santri harus memiliki sikap seperti yang telah dimiliki oleh Kiai dan para ustad. Santri sangat memperhatikan gerak dan langkah ustadnya untuk di tiru dan diterapkan dalam kehidupan sehari-hari di pondok pesantren.

Pondok pesantren sangat mengutamakan pendidikan akhlak. Pembelajaran daring yang bersifat transfer of knowledge tidak mampu menjamah sisi hati peserta didik yang paling dalam jika tidak ada keteladanan yang di bangun. Dengan tidak bermaksud mengkultuskan seseorang, ketokohan seorang kiai di dalam pesantren bagi santri dan warganya dapat diidentikkan dengan kedudukan Nabi di dalam kehidupan para sahabat ketika itu. Semua perilaku Nabi selalu dicermati oleh para sahabat untuk diikuti karena yang demikian itu merupakan bagian dari pembelajaran ajaran Islam kepada para sahabatnya sebagai pelangsung risalah Nabi. Begitu halnya seorang kiai, sikap dan perilakunya selalu dijadikan panutan bagi seluruh warga pesantren. Kiai merupakan figur sentral di dalam kehidupan pesantren sehingga keteladanan seorang kiai menjadi ruh pesantren.

Selain itu pembelajaran daring kurang optimal dan belum dikemas dengan baik. Tidak semua santri memiliki gawai atau terganggunya sinyal internet, menyebabkan kurang menyentuhnya aspek afektif dan psikomotorik. Orang tua santri juga belum siap menggantikan peran ustad, tidak semua dari walisantri 
yang mumpuni dalam mengajar materi Fikih sebagai contoh, apalagi mempunyai sanad keilmuan Fikih yang diajarkan itu, selain itu beban lain dari santri yang semakin berat ketika belajar daring serta terganggunya psikologis seperti timbulnya rasa jenuh pada santri.

Dalam konteks santri, belajar menghadap guru merupakan hal yang sangat penting. Transformasi pembelajaran dari tatap muka kepada luring membuat santri semakin tidak bebas dan kurang begitu mau karena alasan sanad keilmuan. Sanad keilmuan yang bisa dirasakan langsung saat mereka bertatap muka dengan guru dan kiai mereka, serta tradisi berjabat tangan saat guru atau kiai memberikan ijazah kitab yang dibacanya menjadi suatu keyakinan akan keberkahan ilmu yang mereka dapatkan. Oleh karena itu penulis tertarik untuk melakukan penelitian tentang bagaimana resistensi pondok pesantren dalam mengelola santri di masa pandemic Covid-19 ini.

\section{METODE}

Metode pembahasan dalam artikel ini menggunakan studi literatur dengan penguraian, perangkuman, serta penarikan kesimpulan dan berusaha untuk memunculkan gagasan-gagasan baru yang relevan dan mutakhir untuk dilakasanakan di dalam sistem manajemen pondok pesantren. Dilihat dari sifatnya, maka penelitian ini termasuk penelitian deskriptif. Penelitian deskriptif berfokus pada penjelasan sistematis tentang fakta yang diperoleh saat penelitian dilakukan.

Studi literatur merupakan penelitian yang dilakukan oleh peneliti dengan mengumpulkan sejumlah buku buku, majalah yang berkaitan dengan masalah dan tujuan penelitian (Danial \& Wasriah, 2009). Dalam proses pengumpulan data studi literatur dibutuhkan tiga proses penting, yaitu editing, organizing dan finding. Editing yaitu pemeriksaan kembali data yang diperoleh terutama dari segi kelengkapan, kejelasan makna dan keselarasan makna antara yang satu dengan yang lain. Organizing yaitu mengorganisir data yang diperoleh dengan kerangka yang sudah diperlukan. Dan finding yaitu melakukan analisis lanjutan terhadap hasil pengorganisasian data dengan menggunakan kaidah-kaidah, teori dan metode yang telah ditentukan sehingga ditemukan kesimpulan yang merupakan hasil jawaban dari rumusan masalah (Awwaabiin, 2021).

\section{HASIL DAN PEMBAHASAN}

Pengelolaan santri dalam pondok pesantren agar terhindar dari Covid-19 merupakan ikhtiar wajib yang harus dilaksanakan oleh pondok pesantren. Sejatinya pengelolaan santri pada masa pandemi Covid-19 merupakan tantangan yang begitu berat bagi pesantren, apalagi pesantren dengan jumlah santri besar. Namun usaha yang besar ini akan dapat dilaksanakan pesantren apabila terdapat kerjasama yang baik secara substantif antara Kiai dan pengurus pondok, santri, pemerintah setempat, wali santri dan masyarakat sekitar. Fungsi dari kerjasama ini adalah sebagai kontrol terhadap kegiatan santri yang melanggar protokol kesehatan baik di lingkungan pesantren atau di luar lingkungan pesantren apabila santri keluar karena ada keperluan yang mendesak.

Bentuk usaha meresistensi pondok pesantren terhadap Covid-19 di pesantren ada 2 hal yang harus diperhatikan oleh pesantren yaitu keadaan 
kesehatan santri sebelum masuk pondok, dan kesehatan santri selama di pondok. Dalam memantau kesehatan santri sebelum masuk pondok, pihak pengurus harus menetapkan syarat yang ketat sehingga ketika mereka masuk benar-benar dalam keadaan sehat, yaitu harus melaksanakan SWAB/Rapid Antigen sehingga mereka saat ke pondok membawa surat keterangan negatif Covid-19. Selain itu santri masuk pondok harus dalam keadaan sehat dan tidak menunjukkan gejala sakit terutama gejala Covid-19 seperti suhu badan tinggi atau terjadi demam, batuk, pilek, kelelahan, dan lain sebagainya yang termasuk dalam gejala Covid-19. Ketika berada di pondok untuk pertama kali, santri harus melakukan isolasi pada tempat-tempat yang telah ditentukan oleh pihak pondok pesantren, ini menjaga agar santri yang sudah berada di dalam pondok tidak tertular virus yang dibawa oleh santri yang baru datang.

Setelah semua santri telah berada di pondok pesantren mereka diberi edukasi tentang pentingnya menjaga kesehatan dan kebersihan lingkungan pondok. Sehingga setiap santri mengambil peran masing-masing dalam menjaga kebersihan dan kesehatan di lingkungan pondok, agar kesadaran mereka terhadap lingkungan semakin besar.

Manajemen santri dalam masa pandemi Covid-19 merupakan hal yang berbeda dengan pengelolaan santri biasa. Sebelum masa pandemi, pengelolaan menjadi mudah karena tidak ada pembatas yang signifikan diantara para santri sehingga mereka lebih bebas untuk mengadakan kegiatan, namun saat pandemi, mereka diharapkan tidak melakukan hal-hal yang dapat menurunkan imunitas mereka seperti tidur sampai larut malam.

Pengelolaan santri secara fisik setelah seluruh santri berada di pondok pesantren dapat dilakukan agar pesantren bisa resistan terhadap Covid-19 adalah membentuk gugus Covid-19, menyediakan fasilitas protocol kesehatan, program kebersihan lingkungan pondok, program olahraga rutin, penyediaan makanan santri yang higienis, pengurangan jumlah santri dalam satu kamar, santri diberi waktu istirahat yang cukup agar kekebalan tubug tetap terjaga, bertindak cepat apabila terdapat santri yang sakit, pimpinan pesantren ikut serta dalam mengawasi para santri dalam kepatuhan terhadap protocol kesehatan, serta penyesuaian struktur kurikulum. Adapun penjelasan dari pengelolaan tersebut dijelaskan berikut ini.

\section{Membentuk Gugus Covid-19}

Mengadopsi Gugus Tugas Covid-19 yang dibentuk oleh pemerintah, pondok pesantren sangat perlu membentuk gugus tugas ini. Gugus Covid-19 pondok pesantren merupakan gugus tugas yang berupaya untuk mencegah dan menanggulangi dampak dari penyakit Covid-19 di pondok pesantren. Gugus Covid-19 di pondok pesantren memungkinkan dipimpin oleh seorang pengurus yang dipilih oleh dewan masyayikh. Dalam melaksanakan tugasnya, ketua gugus dapat dibantu oleh pengurus-pengurus lain dan tersebar di setiap kamar/komplek pesantren. Mereka bertugas mengkoordinir segala bentuk kegiatan sehingga santri selalu mematuhi protokol kesehatan. Satuan ini berhak untuk memberikan sanksi terhadap santri yang tidak mematuhi protokol kesehatan. Mereke memiliki peran yang signifikan dalam mendisiplinkan para santri yang melanggar. Hal ini dilakukan agar setiap kegiatan yang dilaksanakan berjalan dengan baik tanpa adanya rasa was-was. 
Gugus Covid-19 di pesantren hendaknya memiliki jaringan terhadap dokter/puskesmas terdekat sebagai antisipasi apabila terdapat hal yang terjadi di pesantren. Ketentuan aman ini harus diperhatikan oleh pihak pondok apabila ingin mengadakan pembelajaran tatap muka, apabila ketentuan aman tidak dilaksanakan, maka pondok pesantren tidak dapat menyelenggarakan pembelajaran tatap muka.

Pihak pimpinan pondok pesantren sebaiknya mengkoordinasikan dengan Gugus Tugas Covid-19 dan dinas kesehatan daerah setempat, Menteri Agama Fachrul Razi saat itu mengatakan bahwa koordinasi bertujuan memastikan bahwa asrama dan lingkungannya aman dari Covid-19 serta memenuhi standar protokol kesehatan (Permana \& Hafil, 2020).

\section{Menyediakan Fasilitas Protokol Kesehatan}

Tidak semua santri peduli terhadap kesehatannya sendiri. Oleh karena itu pondok pesantren perlu menyediakan fasilitas protokol kesehatan, seperti menyediakan masker gratis untuk santri, terdapat tempat cuci tangan dengan sabun dan air mengalir di setiap sudut ruangan atau ketersediaan handsanitizer yang memadai terhadap jumlah santri yang ada di setiap ruangan belajar atau ruang asrama.

Fasilitas protokol kesehatan ini mutlak ada sebagai sarana pencegahan terhadap penyebaran penyakit Covid-19 di pondok pesantren. Selain penyediaan secara gratis, di toko dalam pesantren hendaknya menjual alat-alat protokol kesehatan mulai dari penyediaan handsanitizer, masker, sabun antiseptik untuk mandi para santri dan beberapa suplemen makanan seperti madu dan multivitamin.

Selain itu menjaga jarak (physycal distancing) tetap wajib dilaksanakan oleh santri agar semua dapat aman saat berinteraksi di dalam pesantren. Tidak diperkenankan kontak fisik dengan orang lain meskipn itu dengan ustad dan Kiai. Suatu tradisi salim dan cium tangan terhadap Kiai dan Ustad saat bertemu harus diminimalisir jika memungkinkan. Kiai berusaha untuk tidak menyodorkan tangannya saat bertemu dengan santri karena dalam kepercayaan santri, mencium tangan gurunya merupakan perbuatan yang baik dan dapat mendatangkan keberkahan ilmu yang telah didapatkan dari mereka.

Suatu hal yang penting adalah pengecekan suhu setiap pagi. Pengecekan ini dilakukan sebelum santri melaksanakan kegiatan dalam sehari, mereka berkumpul untuk dilakukan pengecekan suhu, bagi santri yang kedapatan memiliki suhu badan tinggi harus segera ada tindakan dan pemisahan dari santri lain (di isolasi) agar santri yang bersangkutan segera mendapatkan pertolongan medis dan tidak terjadi hal-hal yang tidak diharapkan.

\section{Program Kebersihan Lingkungan Pondok}

Sebenarnya tradisi kebersihan pondok selalu dilaksanakan oleh santri setiap libur hari Jumat atau disebut dengan Ro'an. Ro'an yaitu kegiatan mengerahkan seluruh santri putra maupun putri dengan tujuan untuk melakukan pekerjaan yang diharuskan bekerja sama satu sama lain seperti membersihkan lingkungan pondok pesantren (Saini, 2020). Dalam tradisi ini semua santri wajib untuk mengikutinya, mulai membersihkan bilik kamar sampai pada halaman dan seluruh bagian pondok. 
Kesadaran akan kebersihan pondok terutama bilik kamar harus selalu diajarkan kepada santri, karena meraka terpisah jauh dari orang tua dan hidup mandiri di pesantren, dengan segala kesibukan yang ada di pesantren, tidak jarang mereka meletakkan pakaian kotor di gantungan yang berpotensi membuat udara menjadi pengap dan lembab, apalagi jika fentilasi udara dalam kamar kurang. Ini menyebabkan udara kamar menjadi lembap dan mudah untuk tertular penyakit.

Dilansir dari klikdokter.com menyebutkan bahwa kondisi ruangan yang lembap dan tidak memiliki ventilasi bisa memicu terjadinya infeksi paru, karena kuman dan jamur sangat suka tinggal di tempat yang lembap, jika sirkulasi udara tidak bagus, kuman akan ada di tempat itu dan siap untuk menjangkiti para penghuni kamar (Maharani, 2018). Jika santri telah sakit maka akan mudah Covid-19 menjangkiti mereka.

Lingkungan yang nyaman dan favourable berpengaruh besar terhadap perasaan dan pemikiran seseorang. Jadi, pengaruh lingkungan merupakan sesuatu yang tidak dapat dipungkiri, baik lingkungan pergaulan yang dibentuk oleh sikap mental dan alam pikiran masyarakat sekelilingnya maupun keadaan tempat ia hidup dan belajar (Sanusi \& Sanah, 2019).

\section{Program Olahraga Rutin}

Program olahraga di pondok pesantren perlu dilaksanakan karena santri lebih suka tidur dari pada melaksanakan kegiatan yang bersifat fisik. Pelaksanaan program olahraga perlu dikoordinir oleh ketua organisasi pondok yang memungkinkan mampu menggerakkan para santri agar mau berolahraga setiap hari. Olahraga di lingkungan pondok menjadi suatu hal yang sulit bagi santri apabila mereka telah terbiasa tidur setelah subuh atau setelah mereka mengaji bersama Kiai atau ustad.

Kebanyakan santri tidur setelah subuh karena mereka tidur terlalu malam, mereka berbicara satu sama lain sampai larut malam. Hal ini perlu didisiplinkan agar mereka tetap terjaga imunitasnya dan tetap terjaga kesehatannya. Kebiasaan yang telah menjadi hal yang biasa ini mungkin sangat sulit untuk dilaksanakan di awal, namun karena peraturan yang memiliki sanksi membuat mereka sedikit menjadi berfikir tentang kesehatan dari pada harus begadang malam hanya untuk berbicara dengan teman-temannya.

Aktifitas fisik dapat menjadi salah satu cara untuk mencegah penularan virus Covid-19 ini. Pasalnya, menurut hasil penelitian, orang yang rutin berolahraga lebih jarang terserang penyakit dibandingkan dengan orang yang jarang berolahraga. Hal ini disebabkan karena ketika anda berolahraga, kinerja sel darah putih akan terangsang. Sel darah putih ini yang berfungsi sebagai antibodi untuk melawan berbagai jenis kuman yang masuk ke dalam tubuh. Olahraga dipercaya dapat membantu mengeluarkan bakteri dari paru-paru yang memungkinkan tubuh terkena gejala flu dan penyakit lainnya. Ketika olahraga, suhu tubuh juga mengalami peningkatan. Hal ini dapat menghambat bakteri untuk berkembang dalam tubuh, dan dengan suhu tubuh yang meningkat juga dapat membantu tubuh melawan infeksi. Selain itu, dengan aktif berolahraga juga dapat mengurangi hormon stres di tubuh dan memperbanyak hormon endorfin yang berguna untuk sebagai obat penghilang sakit alami dan penyenang suasana hati (hormon bahagia) (Fernandes, 2020). 


\section{Penyediaan Makanan Santri yang Higienis}

Penyediaan makan yang higienis dan bergizi di pondok pesantren merupakan hal yang tidak sulit karena santri saat ini banyak yang makan di indekos dan tidak banyak yang masak sendiri. Sehingga ketika mereka ikut makan di dalam indekos, kedisiplinan makan mereka akan tetap terjaga. Makanan higienis dan bergizi merupakan suatu hal yang penting bagi santri, mereka melaksanakan kegiatan hampir 16-18 jam setiap hari. Mereka istirahat untuk tidur hanya sekitar 6-7 jam setiap hari, apalagi ketika kegiatan mereka penuh mulai bangun tidur sampai tidur lagi. Sehingga kebutuhan akan gizi yang seimbang sangat diperlukan dalam rangka melaksanakan kegiatan dengan tetap terjaga kesehatannya.

Selain penyediaan makanan yang higienis, cara makan santri juga harus diatur sedemikian rupa agar tidak terjadi kerumunan besar saat makan. Mereka tetap bisa jaga jarak aman dan makan dengan tata cara yang baik sesuai dengan tuntunan agama Islam.

Menurut penelitian yang dilakukan di Pesantren Gorontalo menyebutkan bahwa nilai gizi makanan terutama energi hanya sekitar $76 \%$ dari kebutuhan total santri (Taqhi, 2014). Padahal kebutuhan kalori dan nutrisi masa remaja lebih besar dibandingkan masa pertumbuhan, kecuali pada saat bayi (Andrews, 2010). Management service food and beverange atau pengelolaan makanan dan minuman sehat menjadi sangat penting di pondok pesantren ini. Pengelolaan makanan di pondok pesantren sementara ini dilakukan secara sederhana, belum mendapatkan arahan yang semestinya dari tenaga yang kompeten di bidang nutrisi ataupun ahli gizi. Pada kelas remaja yang dilakukan di pondok pesantren ini sebelumnya, beberapa remaja atau santri mengalami konstipasi dan mengeluh jarang makan sayuran dan buah-buahan. Remaja putri seharusnya mendapatkan perhatian khusus tentang pemenuhan zat-zat gizi khususnya mikronutrien yang terdiri dari vitamin dan mineral, yang diperoleh dari sayur dan buah-buahan. Pemenuhan kebutuhan akan zat mikronutrien ini erat kaitannya dengan fungsi sistem reproduksi dikemudian hari bagi remaja putri (Dewi et al., 2020)

\section{Pengurangan Jumlah Santri dalam Satu Kamar.}

Dalam satu bilik kamar, biasanya terdapat antara 10 sampai 15 santri, ini menjadi suatu resiko tersendiri. Para santri yang terlalu banyak dibarengi dengan banyaknya lemari pakaian dan buku serta menjadi satu dengan pakaian yang sudah kotor menyebabkan kamar menjadi terasa semakin sempit. Dalam mencegah penyebaran Covid-19, hendaknya pihak pengurus menambah jumlah kamar dan mengurangi jumlah santri dalam 1 kamar sehingga ruang kamar mereka menjadi lebih lebar dan sirkulasi udara menjadi lebih leluasa. Hal ini sesuai dengan pernyataan seorang legislator Jawa Barat yaitu Ledia Hanifa Amaliah yang mengatakan bahwa pemberlakuan protokol kesehatan harus ketat. Termasuk mengurangi kapasitas anak dalam satu kamar hingga 50\% (Panjaitan, 2020).

Selain pengurangan jumlah santri dalam satu kamar, penerapan larangan berkunjung ke kamar lain perlu diterapkan agar santri tidak mengadakan kunjungan ke kamar santri lain yang memungkinkan agar tidak terpapar virus 
Covid-19. Dan hal ini juga merupakan salah satu penerapan dari physical distancing.

\section{Santri Diberi Waktu Istirahat yang Cukup agar Kekebalan Tubuh Tetap Terjaga.}

Istirahat yang cukup dapat memperkuat sistem imun tubuh santri. Sejalan dengan lansiran laman hellosehat.com bahwa dalam sebuah riset membuktikan manfaat istirahat yang cukup, salah satunya adalah mampu memperbaiki sistem kekebalan tubuh dalam melawan infeksi penyakit (Puji, 2021).

Fakta mengenai tidur cukup untuk menjaga dan meningkatkan imunitas tubuh, sudah dibuktikan dalam berbagai penelitian. Salah satunya yang diterbitkan dalam The Journal of Experimental Medicine. peneliti sudah membuktikan berbagai manfaat tidur, salah satunya mampu memperbaiki sistem kekebalan tubuh dalam melawan berbagai infeksi penyakit. Dari penelitian ini, diketahui bahwa istirahat yang cukup bisa memperbaiki kinerja sel imun, khususnya limfosit $\mathrm{T}$ yang berperan dalam melawan infeksi. Antibodi tersebut biasanya aktif menyerang virus penyebab flu, HIV, herpes, hingga sel kanker. Masih dari penelitian yang sama, ditemukan pula mekanisme baru mengenai bagaimana tidur dapat memperbaiki sistem kekebalan tubuh. Ketika sel limfosit $\mathrm{T}$ mengenali adanya infeksi penyakit yang masuk ke tubuh, integrin akan diaktifkan. Integrin adalah sejenis protein lengket yang memungkinkan sel limfosit $\mathrm{T}$ dapat menempel dan membunuh sel-sel yang terinfeksi. Peneliti membuat perbandingan sel limfosit $\mathrm{T}$ dari dua kelompok berbeda. Yaitu kelompok yang diminta untuk tidur, dan kelompok yang tetap terjaga semalaman. Hasilnya, ditemukan bahwa sel limfosit T pada kelompok yang tidur bisa bekerja lebih baik. Kondisi ini membuat integrin yang aktif kian bertambah. Jadi, sel limfosit $\mathrm{T}$ dapat mendeteksi lebih banyak sel yang mungkin terinfeksi. Hal ini diyakini terjadi karena ketika tidur, kadar hormon adrenalin, noradrenalin, dan prostaglandin menurun. Poin ini yang memengaruhi kinerja sel limfosit T. Jika dibandingkan dengan kelompok yang terjaga, hormon stres justru meningkat dan menghambat kemampuan sel T untuk berfungsi optimal. Akibatnya, seseorang yang tidak mendapat istirahat yang cukup lebih rentan sakit (Puji, 2021).

Santri dengan kondisi tidur yang cukup akan menjadi lebih sehat dari pada santri dengan kondisi kurang tidur, akibatnya kondisi kurang sehat pada santri lebih rentan terserang penyakit. Keamanan pondok harus lebih ekstra mendisiplinkan santri yang terbiasa tidur larut malam, sehingga mereka bisa bangun untuk salat tahajjud dengan keadaan yang sehat dan terjaga kondisi daya tahan tubuhnya.

\section{Bertindak Cepat Bila Ada Santri yang Sakit.}

Setiap hari harus ada pengecekan suhu tubuh, ini dilakukan dengan tujuan agar pengurus dan pimpinan pondok pesantren lebih dini mengetahui keadaan santri yang sakit. Keadaan apapun yang dialami oleh santri wajib diketahui oleh pengurus agar dapat ditangani dengan cepat dan tepat.

Gejala penyakit terutama Covid-19 harus bisa terdeteksi sejak awal sehingga tidak menyebar ke santri yang lain, selain kecepatan dan ketepatan pengobatan, isolasi santri yang mengalami gejala harus dilakukan dan mereka 
tidak diizinkan untuk bergaul dengan teman lainnya sampai mereka sembuh total dari penyakit yang tengah dideritanya.

Kesadaran santri dalam mendeteksi dini keberadaaan penyakit merupakan awal dari kesembuhan, dan merupakan hal yang sangat penting untuk menekan resiko tertular penyakit Covid-19. Di sini peran pimpinan pondok pesantren sangat penting karena santri sangat patuh terhadap Kiai atau Ustad yang mengajar mereka.

Jika kehidupan di beberapa pondok pesantren yang selama ini merupakan perilaku hidup yang beresiko, maka hendaknya pada masa pandemi ini, kecepatan dalam menanggapi santri yang sakit wajib ditingkatkan agar semua tetap dalam keadaan sehat dan dengan kondisi psikis yang baik pula. Pondok pesantren harus meminimalisir resiko dari kebiasaan pola hidup dan berusaha untuk menghilangkan pola hidup beresiko tersebut.

\section{Pimpinan Pesantren Ikut Serta Dalam Mengawasi Para Santri Dalam Kepatuhan Terhadap Protokol Kesehatan.}

Pimpinan pondok bertanggung jawab terhadap semua kegiatan dan segala aktifitas yang terjadi di dalam pondok. Hendaknya mereka tidak menutup diri dan antipasti terhadap merebaknya pandemi Covid-19, namun menjadi orang-orang yang memberikan semangat kepada masyarakat terutama kepada santri.

Sejak dahulu pondok pesantren menjadi garda terdepan dalam hal apapun dengan Kiai yang menjadi tonggak ujungnya. Pesantren sebagai rumah kedua para santri dan Kiai adalah orang tua kedua santri mempunyai kewajiban untuk memikirkan kemaslahatan kehidupan santri dibandingkan diri dan keluarganya.

Peningkatan kewaspadaan Kiai dan Ustad dan partisipasi mereka dalam pengawasan terhadap santri yang melanggar protokol kesehatan menjadi suatu hal yang sangat penting. Dan ini adalah tantangan berat bagi para Kiai agar santri tidak terpapar Covid-19, karena menghadapi santri yang bandel itu jauh lebih ringan dibandingkan dengan tantangan menghadapi Covid-19.

\section{Penyesuaian Struktur Kurikulum}

Selain itu di lingkup kurikulum pesantren, perlu adanya perubahan yang sesuai dengan karakteristik pembelajaran di masa pandemi dan tetap efektif dalam transfer ilmu pengetahuan dan agama kepada santri. Dalam pembelajaran pengelola pesantren hendaknya mengurangi jadwal kegiatan, menyediakan kelas daring dengan sistem blended learning membuka pesantren virtual dalam rangka mewadahi para santri dewasa yang masih ingin mengaji kepada para kiai.

Kurikulum pesantren dan kegiatan yang penuh dapat mengakibatkan para santri kelelahan, oleh karena itu pada masa pandemi Covid-19 tidak perlu dilakukan kegiatan yang penuh. Demi menjaga kesehatan santri, hendaknya pihak pondok tidak terlalu memaksakan para santri.

\section{SIMPULAN}

Dari pembahasan di atas dapat disimpulkan bahwa pesantren dalam masa pandemi Covid-19 apabila ingin melaksanakan tatap muka harus memperhatiakan manajemen santri yang terencana dan terstruktur dengan baik 
agar dapat resistan terhadap Covid-19. Dan pesantren harus siap dengan segala resiko yang ada pada masa pandemi. Secara fisik, resistensi pesantren dalam mengelola santri di masa pandemi Covid-19 dapat dilakukan dengan membentuk gugus Covid-19, menyediakan fasilitas protokol kesehatan, program kebersihan lingkungan pondok, program olahraga rutin, penyediaan makanan santri yang higienis, pengurangan jumlah santri dalam satu kamar, santri diberi waktu istirahat yang cukup agar kekebalan tubuh tetap terjaga, bertindak cepat bila ada santri yang sakit, serta para pimpinan pesantren ikut serta dalam mengawasi para santri dalam kepatuhan terhadap protokol kesehatan. Selain itu di lingkup kurikulum pesantren, perlu adanya perubahan yang sesuai dengan karakteristik pembelajaran di masa pandemi dan tetap efektif dalam transfer ilmu pengetahuan dan agama kepada santri, dalam pembelajaran pengelola pesantren hendaknya mengurangi jadwal kegiatan.

\section{REFERENSI}

Andrews, G. (2010). Buku Ajar Kesehatan Reproduksi Wanita. Penerbit Buku Kedokteran EGC.

Awwaabiin, S. (2021). Studi Literatur: Pengertian, Ciri-Ciri, dan Teknik Pengumpulan Datanya. Penerbitdeepublish.Com. https://penerbitdeepublish.com/studi-literatur/

Danial, E., \& Wasriah, N. (2009). Metode Penulisan Karya IImiah. Laboraturium Pendidikan Kewarganegaraan.

Dewi, M., Ulfah, M., Wati, F., Hastuti, N., Rizani, R., \& Dini, C. (2020). Pengelolaan Makanan Sehat Di Pondok Pesantren Guna Meningkatkan Kesehatan Reproduksi Remaja. Warta Pengabdian, 14(2), 122-133. https://doi.org/10.19184/wrtp.v14i2.17567

Fernandes, R. (2020). Manfaat Olahraga Untuk Mencegah Virus COVID-19. Arsip Sehat. https://arsipsehat.com/2020/04/14/manfaat-olahraga-untukmencegah-virus-covid-19/

Firmansyah, R. (2020). Ini Syarat Madrasah dan Pesantren yang Diperbolehkan Gelar KBM Tatap Muka. Prfmnews.Pikiran-Rakyat.Com. https://prfmnews.pikiran-rakyat.com/nasional/pr-13658789/ini-syaratmadrasah-dan-pesantren-yang-diperbolehkan-gelar-kbm-tatap-muka

Haniek, S. I. (2020). Pesantren Bina Umat pada Masa New Normal. Al-Riwayah : Jurnal Kependidikan, 12(2), 287-300. https://doi.org/10.47945/alriwayah.v12i2.288

Kahfi, S., \& Kasanova, R. (2020). Manajemen Pondok Pesantren Di Masa Pandemi Covid-19. Pendekar: Jurnal Pendidikan Berkarakter, 3(1), 26-30. https://doi.org/10.31764/pendekar.v3i1.2827

Maharani, A. (2018). Waspada, Kamar Lembap Rentan Picu Infeksi Paru. Klikdokter. https://www.klikdokter.com/info-sehat/read/3617556/waspadakamar-lembap-rentan-picu-infeksi-paru

Panjaitan, R. (2020). Soal Pesantren, Kapasitas Santri Tiap Kamar Perlu Dikurangi 50\%. KumparanNews. https://kumparan.com/kumparannews/soal-pesantren-kapasitas-santri-tiapkamar-perlu-dikurangi-50-1tdQmCCq9g3/full

Permana, F. E., \& Hafil, M. (2020). Imbauan Kemenag Untuk Pesantren yang akan 
H. Q. Mubah

https://www.republika.co.id/berita/qc68d5430/imbauan-kemenag-untukpesantren-yang-akan-tatap-muka

Puji, A. (2021). 4 Manfaat Istirahat yang Cukup, Plus Cara Memperolehnya. Hellosehat.Com. https://hellosehat.com/pola-tidur/tips-tidur/manfaatistirahat-yang-cukup/

Saini, M. (2020). Tradisi Ro'an (Kerja Bakti) dalam Meningkatkan Karakter Sosial Santri di Pondok Pesantren AI-Qomar Wahid Patianrowo Nganjuk. TASYRI': Jurnal Tarbiyah-Syari'ah Islamiyah, 27(2), 70-83. http://ejournal.kopertais4.or.id/pantura/index.php/tasyri/article/view/3565

Sanusi, H. P., \& Sanah, S. (2019). Optimalisasi Manajemen Program Bi'Ah Lughawiyah Sebagai Upaya Meningkatkan Penguasaan Keterampilan Berbahasa Arab. Jurnal Isema : Islamic Educational Management, 2(1), 1124. https://doi.org/10.15575/isema.v2i1.4993

Taqhi, S. A. (2014). Gambaran Sistem Penyelenggaraan Makanan di Pondok Pesantren Hubulo Gorontalo. MKMI: Media Kesehatan Masyarakat Indonesia, 2(1), 241-247. https://journal.unhas.ac.id/index.php/mkmi/article/view/507 